\title{
INVENTARISASI TUMBUHAN BAWAH DI KAWASAN HUTAN TAMAN WISATA ALAM SIBOLANGIT, KABUPATEN DELI SERDANG
}

\section{Inventory Plant Down In The Forest Surround Of Natural Tour Park Sibolangit, District Deli Serdang}

\author{
Wina Dyah Puspita Sari ${ }^{1}$, Aryeni2) \\ Program Studi Biologi FMIPA Universitas Negeri Medan \\ Jl. Williem Iskandar Pasar V Medan 20221 \\ *Corresponding author: E-mail: $\underline{\mathrm{w}}$ dvahpuspitasari@vahoo.co.id
}

\begin{abstract}
Abstrak
Tumbuhan bawah adalah tumbuhan yang berupa tanaman herba dan semak serta tanaman rendah yang menutupi bagian bawah suatu kawasan hutan. Dengan demikian fungsi tanaman di sini adalah untuk menahan daya perusak butir butir hujan yang jatuh dan derasnya aliran air di atas permukaan tanah. Taman Wisata Alam Sibolangit adalah merupakan kawasan hutan dengan luas area $\pm 24,85$ Ha. Keberadaan tumbuhan bawah di Taman Wisata Alam Sibolangit menjadi daya tarik tersendiri bagi pengunjung.Tujuan penelitian adalah untuk memperoleh data inventarisasi tumbuhan bawah dan mendeskripsikan karakter-karakter morfologinya. Penelitian dilakukan dengan menggunakan metode eksplorasi di sepanjang jalur Taman Wisata Alam Sibolangit. Dari penelitian yang telah dilakukan diperoleh 48 jenis tumbuhan bawah yang terdiri dari 31 famili. Dari 48 jenis tumbuhan bawah yang telah diidentifikasi, 30 diantaranya termasuk ke dalam divisi Spermatophyta, sedangkan 18 lain sisanya adalah termasuk ke dalam divisi Pterydophyta.
\end{abstract}

Kata Kunci : Inventarisasi, Morfologi, Tumbuhan bawah,Taman Wisata Alam Sibolangit

\begin{abstract}
Underwater plants are plants in the form of herbaceous plants and shrubs and low plants that cover the bottom of a forest area. Thus the function of the plant here is to withstand the destructive power of the falling rain fall and the rapid flow of water above the soil surface. Sibolangit Nature Park is a forest area with an area of $\pm 24.85 \mathrm{Ha}$. The existence of the lower plants in Sibolangit Nature Park become the main attraction for the visitors. The purpose of the research is to obtain the inventory data of the lower plants and describe the characters morphology. The research was conducted by using the exploration method along the path of Sibolangit Nature Park. From the research that has been done, there are 48 types of plants that consist of 31 families. Of the 48 undersea species identified, 30 of them belong to the Spermatophyta division, while the remaining 18 are included in the Pterydophyta division.
\end{abstract}

Keywords: Inventory, Morphology, Landscapes, Sibolangit Nature Park

How to Cite: Sari, W.D.P. dan Aryeni. 2017, Invetarisasi Tumbuhan Bawah di Kawasan Taman Wisata Alam Sibolangit, Kabupaten Deli Serdang, , BioLink, Vol. 4 (1): Hal. 41-53 
Sari, W.D.P., dan Aryeni, Inventarisasi Tumbuhan Bawah di Kawasan Hutan Taman Wisata

\section{PENDAHULUAN}

Tumbuhan bawah adalah tumbuhan yang berupa tanaman herba dan semak serta tanaman rendah yang menutupi bagian bawah suatu kawasan hutan. Dengan demikian fungsi tanaman di sini adalah untuk menahan daya perusak butir butir hujan yang jatuh dan derasnya aliran air di atas permukaan tanah karena tumbuhan bawah menambah bahan organik tanah dan melakukan transfer yang memperbesar kemampuan tanah untuk menyerap dan menahan aliran air hujan yang jatuh.

Tumbuhan bawah merupakan komunitas tumbuhan penyusun lantai hutan bagian bawah dekat permukaan tanah. Tumbuhan ini umumnya berupa rumput, herba, semak atau perdu rendah. Jenis-jenis vegetasi ini ada yang bersifat annual, biannual, atau perenial dengan bentuk hidup soliter, berumpun, tegak menjalar atau memanjat. Jenisjenis yang menyusun tumbuhan bawah umumnya anggota dari suku-suku poaceae, cyperaceae, araceae, asteraceae, paku-pakuan dan lain-lain.

Taman Wisata Alam Sibolangit adalah merupakan kawasan hutan dengan luas area $\pm 24,85$ Hasecara administratif pemerintahan terletak di Desa Sibolangit Kecamatan Sibolangit Kabupaten Deli Serdang, Provinsi Sumatera Utara. TWA Sibolangit umumnya ditumbuhi pepohonan yang besar dengan diameter lebih dari satu meter, diantaranya pepohonan Sono Kembang (Dalbergia latifolia), pepohonan Angsana (Ptrocarpus indicus), Sungkai Khihujan, ada juga jenis pohonan palm dan pinang. Disamping itu terdapat pula tumbuhan yang merambat seperti Philodendron sp.Di
Taman Wisata Alama Sibolangit juga ditemukan salah satu tumbuhan yang tergolong langka dan mempunyai daya tarik tersendiri yaitu Bunga Bangkai (Amorphophallus titanum).

Keberadaan tumbuhan bawah di Taman Wisata Alam Sibolangit menjadi daya tarik tersendiri bagi pengunjung. Kawasan tersebut banyak terdapat pohon-pohon dengan diameter batang yang besar, sehingga tumbuhan bawah didominasi oleh jenis-jenis tumbuhan perintis yang tidak memerlukan banyak cahaya matahari untuk keberlangsungan hidupnya.Akan tetapi, data-data mengenai keberadaan tumbuhan bawah yang ada di kawasan hutan Taman Wisata Alam Sibolangit belum dapat diketahui secara lengkap, baik itu dari nama jenisnya ataupun dari morfologinya. Sehingga dirasa perlu bagi penulis untuk melakukan inventarisasi tumbuhan, khususnya tumbuhan bawah yang ada di kawasan tersebut. Hasil studi ini diharapkan akan memberikan informasi yang jelas dan lengkap mengenai keberadaan jenis jenis tumbuhan bawah yang ada di kawasan Hutan Taman Wisata Alam Sibolangit.

\section{METODE PENELITIAN}

Penelitian ini dibagi menjadi dua tahap, yaitu: (1) tahap pelaksanaan; dan (2) tahap identifikasi dan pembuatan spesimen herbarium.Metode pengambilan data yang digunakan di lapangan adalah metode eksplorasi yaitu menjelajah lokasi dan mengoleksi semua jenis tumbuhan bawahyang ditemukan untuk mendapatkan gambaran detail dari persebaran dan kekayaan jenis. 


\section{Prosedur Kerja}

Melakukan pengambilan sampel yang mengacu pada Rugayah et al. (2004) dimana diusahakan memperoleh koleksi yang subur (fertil), dan mengambil semua bagian yang ada pada tumbuhan tumbuhan bawah tersebut, mencatat parameter yang terdapat di lapangan, antara lain tempat hidup, warna pada daun, bunga, aroma daun dan lain-lain. Lalu mengoleksi sampel tumbuhan dan memberikan label gantung pada tiap sampel yang dikoleksi, kemudian dibuat menjadi spesimen koleksi dengan meletakkan spesimen di antara kertas koran dan diawetkan dengan alkohol 70\% untuk mencegah kontaminasi jamur dan pembusukan.Setelah pengamatan di lapangan berakhir, tumbuhan bawah yang telah dikoleksi dibuka kembali dan disusun sedemikian rupa untuk dikeringkan dalam oven pengering pada temperatur $\pm 60^{\circ}$ C selama 24 jam. Setelah spesimen telah benar-benar kering diidentifikasi dengan menggunakan buku-buku identifikasi.

\section{HASIL DAN PEMBAHASAN}

Dari penelitian yang telah dilakukan, diperoleh 48 jenis tumbuhan bawah yang terdiri dari 31 famili, seperti yang tertera pada tabel di bawah ini (Tabel. 1).Dari 48 jenis tumbuhan bawah yang telah diidentifikasi, 30 diantaranya termasuk ke dalam divisi Spermatophyta, sedangkan 18 lain sisanya adalah termasuk ke dalam divisi Pterydophyta.

Tabel. 1 Jenis-jenis tumbuhan bawah di Kawasan Taman Wisata Alam Sibolangit

\begin{tabular}{|c|c|c|}
\hline \multirow{2}{*}{\multicolumn{3}{|c|}{$\begin{array}{l}\text { No. Nama tumbuhan } \\
\text { Spermatophyta }\end{array}$}} \\
\hline & & \\
\hline 1. & Ageratum conyzoides & Asteraceae \\
\hline 2. & Crassocephalum crepidiodes & Asteraceae \\
\hline 3. & Piper betle & Piperaceae \\
\hline 4. & Panicum sellowii & Poaceae \\
\hline 5. & Axonopus compressus & Poaceae \\
\hline 6. & Amydrum medium & Araceae \\
\hline 7. & Dieffenachia amoena & Araceae \\
\hline 8. & Rhapidophora spp & Araceae \\
\hline 9. & Scindapsus spp & Araceae \\
\hline 10. & Arum palaestinum & Araceae \\
\hline 11. & Spathiphyllum commutatum & Araceae \\
\hline 12. & Tacca chantrieri & Taccaceae \\
\hline 13. & Calathea lancifolia & Marantaceae \\
\hline 14. & Donax cannaeformis & Marantaceae \\
\hline 15. & Clidemia hirta & Melastomataceae \\
\hline 16. & Curculigo orchioides & Amarylidaceae \\
\hline 17. & Coffea robusta & Rubiaceae \\
\hline 18. & Sauropus androgynus & Euphorbiaceae \\
\hline 19. & Acalypha siamensis & Euphorbiaceae \\
\hline 20. & Blamcanda chinensis & Iridaceae \\
\hline 21. & Pellionia repens & Urticaceae \\
\hline 22. & Hydrocotyle spp & Lamiaceae \\
\hline 23. & Pandanus spp & Pandanaceae \\
\hline
\end{tabular}


Sari, W.D.P., dan Aryeni, Inventarisasi Tumbuhan Bawah di Kawasan Hutan Taman Wisata

\begin{tabular}{lll}
\hline 24. & Musa acuminata & Musaceae \\
25. & Justicia gendarussa & Acanthaceae \\
26. & Strobilanthes spp & Acanthaceae \\
27. & Costus speciosus & Costaceae \\
28. & Costus malortienus & Costaceae \\
29. & Abrus spp & Fabaceae \\
30. & Bauhinia spp & Fabaceae \\
\hline Pterydophyta & \\
\hline 31. & Davallia trichomonides & Davalliaceae \\
32. & Davallia spp & Davalliaceae \\
33. & Diplazium esculentum & Woodsiaceae \\
34. & Stenochlaena palustris & Blechnaceae \\
35. & Lygodium palmatum & Lygodiaceae \\
36. & Lygodium circinatum & Lygodiaceae \\
37. & Angiopteris evecta & Angipteraceae \\
38. & Phymatosorus scolopendria & Polypodiaceae \\
39. & Adiantum latifolium & Pteridaceae \\
40. & Pteris spp & Pteridaceae \\
41. & Dryopteris spp1 & Dryopteriaceae \\
42. & Dryopteris spp2 & Dryopteriaceae \\
43. & Dryopteris spp3 & Dryopteriaceae \\
44. & Gleichenia linearis & Gleicheniaceae \\
45. & Gleichenia spp & Gleicheniaceae \\
46. & Nephrolepis biserrata & Nephrolepidaceae \\
47. & Selaginella willdenowii & Selaginellaceae \\
48. & Asplenium nidus & Aspleniaceae \\
\hline
\end{tabular}

oleh rambut-rambut halus berwarna

Famili dari divisi Spermatophyta yang paling banyak ditemukan jenisnya adalah famili Araceae sebanyak 6 jenis. Kawasan hutan Taman Wisata Alam Sibolangit merupakan daerah dataran tinggi dengan kelembaban udara yang tinggi. Faktor fisik lingkungan pada daerah ini sangat mendukung tumbuhnya jenis jenis tumbuhan dari famili Araceae. Famili dari divisi Pterydophyta yang paling banyak ditemukan jenisnya adalah famili Dryopteriaceae sebanyak 3 jenis.

\section{Deskripsi Jenis}

Ageratum conyzoides L.

Habitat. Teresterial. Habitus. Terna/Herba annual. Akar. Serabut. Batang. Tegak, herbaceous, ditutupi putih, tinggi 30-80 cm. Daun. Bentuk ovate, berhadapan berseling, ujung runcing, pangkal runcing, tepi bergerigi, pertulangan menyirip, terdapat trikoma glandular pada permukaannya. Perbunggaan. Terdapat $30-50$ bunga berwarna merah muda, putih atau ungu yang tersusun berbentuk seperti cawan.

Crassocephalum crepidiodes (Benth).

\section{S. Moore}

Habitat. Teresterial. Habitus. Terna. Akar. Serabut. Batang. Tegak, herbaceous, tinggi 50-100 cm, berambut. Daun. Berbentuk eliptic hingga ovate, berukuran 10-20 cm, ujung runcing, pangkal bertoreh dengan sepasang stipula, tepi bergigi, daun pada bagian atas lebih kecil, petiolus 
berukuran $4 \mathrm{~cm}$. Perbungaan. Berwarna kemerahan.

\section{Piper betle L.}

Habitat. Teresterial, epifit. Habitus. Terna,semak. Akar. tunggang, memiliki modifikasi akar pelekat. Batang. Herbaceous, memanjat. Daun. Berbentuk oval hingga berbentuk jantung, ujung runcing, pangkal membulat hingga berlekuk, berukuran 7-10 cm, pertulangan menjari, tepi rata. Perbunggaan. Bunganya majemuk berbentuk bulir dan terdapat daun pelindung $\pm 1 \mathrm{~mm}$ berbentuk bulat panjang. Pada bulir jantan panjangnya sekitar 1,5 - $3 \mathrm{~cm}$ dan terdapat dua benang sari yang pendek sedang pada bulir betina panjangnya sekitar 1,5 - 6 $\mathrm{cm}$ dimana terdapat kepala putik tiga sampai lima buah berwarna putih dan hijau kekuningan. Buahnya buah buni berbentuk bulat berwarna hijau keabuabuan.

\section{Panicum sellowii}

Habitat. Teresterial. Habitus. rumput tahunan yang memiliki tinggi 60-90 cm Akar. Serabut dalam, buku dan lidah daun berbulu. Batang. Jenis batang batang rumput dengan bentuk bulat atau hampir lonjong. batang tegak, kuat, dan membentuk rumpun.Daun. daun berbentuk lanset, ujung daun meruncing dengan pangkal daun tumpul dan pertulangan daun sejajar yang memiliki panjang daun hingga $90 \mathrm{~cm}$ dan lebar $\pm 10 \mathrm{~mm}$. Pada permukaan daunnya bertekstur kasar, pangkal daun ditutupi oleh rambutrambut yang pendek dan menyebar.

\section{Axonopus compressus}

Habitat. Teresterial. Habitus. Semak, perennial. Akar. Serabut, memiliki stolon. Batang. Merambat, internodus memipih, panjang 3-3.5 cm, berambut halus pada bagian internodus, batang yang tegak didukung oleh nodus yang tertua dengan tinggi kurang lebih $50 \mathrm{~cm}$. Daun. berbentuk pita hingga lanceolate, saling tumpang tindih, ujung obtuse hingga acute. Ligula berupa selaput ciliolate yang pendek. Perbungaan. tersusun dalam bulir, 2-5 bulir, berpasangan, Spikelet tunggal, pipih dengan 2 bunga.

\section{Amydrium medium (Zoll. \& Moritzi) Nicolson}

Habitat. Teresterial.hemiepifit liana hingga $10 \mathrm{~m}$. Habitus. Herba. Akar. tunggang. Batang. (dewasa) memiliki akar pemanjat. Daun. Berbentuk bulat telur (ovate) hingga jantung (cordate), ujung runcing, pangkal berbelah, berukuran 12-45 x 9$25 \mathrm{~cm}$, tangkai daun berukuran panjang 15-35 cm, Perbungaan. Terdiri dari satu atau beberapa tangkai bunga didalam satu rangkaian perbungaan, pedunculus tegak, lebih pendek dibandingkan dengan ptiolus, spata berbentuk ovate, spadix berukuran 4-6 x $1 \mathrm{~cm}$, berwarna putih menuju krem.

\section{Dieffenachia amoena}

Habitat. Teresterial. Habitus. Herba. Akar. Tunggang. Batang. Herba, berukuran sampai dengan 1,5 m. Daun. Berbentuk jorong, ujung meruncing, pangkal membulat, pertulangan menyirip, tepi rata, tangkai daun berpelepah, berwarna hijau dengan 
corak putih dibagian tengah, tangkai daun berukuran 8-10 $\mathrm{cm}$.

\section{Rhapidophora spp}

Habitat. Teresterial. Habitus. HemiEpifit. Akar. tumbuh dari pangkal batang, berbentuk silinder, berupa akar serabut. Batang. batang persegi, tipis berbuku-buku agak rapat, tumbuh tegak ke atas dan jarang bercabang. Daun. Daunbagian bawah berwarna hijau muda-keputihan, sedangk daun bagian atas berwarna hijau agak pekat. Bangun daun berbentuk perisai dengan tulang daun samar, ujung daun meruncing.

\section{Scindapsus spp}

Habitat. Teresterial. Habitus. Herba. Akar. Serabut, dengan rhizome. Batang. Herba. Daun. Bentuk jorong (elliptic), ujung meruncing (acuminate), pangkal membulat, pertulangan daun menyirip, tepi rata, tangkai daun 10-15 $\mathrm{cm}$.

\section{Arum palaestinum}

Habitat.

teresterial.

Habitustanaman herba tahunan.

Akar.berupa akar serabut yang berupa rimpang (umbi). Batang.Tumbuh tegak ke atas dan jarang bercabang. Daun. Pertulangan daun melengkung, tepi daun bertoreh, ujung daun tumpul, helaian bangun tombak atau anak panah, Permukaan daun halus berwarna hijau tua, dengan tangkai yang pada pangkal berubah menjadi upih daun yang seringkali tipis seperti selaput. Bunga. Berukurankecil, dalam jumlah yang besar tersusun sebagai bulir atau tongkol yang mempunyai seludang(spatha).

\section{Spathiphyllum commulatum Schoot.} Habitat. Teresterial.

Habitus.herba. Batang. Herbaceus dengan ciri yang terlihat jelas berbatang (planta caulis) yaitu batang bulat (teres). Ketika muda batangnya berwarna hijau muda, sedangkan pada daun tua berwarna hijau tua. Permukaan batang adalah licin (laevis), dengan arah tumbuh batang tegak (erectus). Daun. daun tunggal yang berwarna hijau dengan filotaksis tersebar. Terlihat daun memiliki permukaan yang luas dengan panjang daun $30 \mathrm{~cm}$ dan lebar $8 \mathrm{~cm}$. Daun lengkap yang memiliki helaian daun (lamina),tangkai daun (petioles),dan pelebah daun (vagina). Bangun daun adalah bulat memanjang(oblongus). Ujung daun adalah meruncing dengan pangkal daun meruncing. Tepi helaian daun adalah rata. Permukaan daun adalah licin dan pertulangan daun menyirip. Perbungaan. Bunga majemuk berbentuk tongkol. tidak memiliki perhiasan bunga, baik corolla maupun calyx. Susunan bunga tongkol disebut spadix yang dilengkapi pelindung yang disebut spatha, Spatha memiliki ujung meruncing dengan pangkal yang tumpul. Di dalam spatha itulah terdapat bunga yang banyak. Bunga betina terlihat seperti tonjolantonjolan kecil, sedangkan bunga jantan tersebar diantara bunga betina.

\section{Tacca chantrieri}

Habitat. Teresterial. Habitus. Herba tahunan tinggi sampai 75 
cm,.Batang. Tegak. Umbi. Bulat gepeng - jorong melebar, berkulit tipis, halus, putih pada yang muda, dan akan berubah menjadi abu-abu tua - coklat. Daun. Daun berpelepah, warna daun hijau tua mengkilat, helaian daun membundar telur sungsang melebar, membundar telur atau melonjongmembundar telur. Pertulangan daun menyirip dengan ujung daun meruncing dan pangkal daun tumpul. Perbungaan.Perbungaan menyerupai payung dengan 20-40 bunga, bratea lembayung atau hitam legam-coklat. Bunga majemuk di ujung didukung oleh daun penumpu yang lebar. Bunga menggenta, kekuningan sampai hitamlembayung-hijau. Buah.Agak membulat, membulat telur sampai melonjong, warna jingga muda.

\section{Calathea lancifolia}

Habitat. Teresterial. Habitus. Herba. Akar. Serabut, berimpang. Batang. Herba. Daun. Bentuknya jorong, ujung runcing, pangkal rata, pertulangan daun menyirip, tepi rata, daun diatur dalam dua baris dengan petioles memiliki basis selubung berbentuk kecil panjang, tangkai daun mungkin bersayap, dan bengkak menjadi pulvinus di pangkalan. Perbungaan. Malai, tertutup oleh bracts spathe, Bunga-bunga kecil dan sering tidak mencolok berwarna hijau muda dan tua berbentuk bulat-bulat dan di baliknya berwarna merah, dan tidak teratur.

\section{Donax cannaeformis}

Habitat. Teresterial. Habitus. herba menahun dengan tinggi 1-2 m, bercabang seperti semak. Akar.serabut. Daun. bentuk helaian daun bulat telur sampai memanjang, panjang daun antara 13-26 cm dan lebarnya antara 4$14 \mathrm{~cm}$, ujung meruncing, pangkal runcing, tepi rata, pertulangan menyirip dengan tulang daun yang rapat. Bunga. berwarna putih bertangkai yang panjangnya dapat mencapai $4 \mathrm{~cm}$. Benang sari tidak sempurna. Buah hampir bulat dengan warna putih dan memiliki rambut halus.

\section{Clidemia hirta}

Habitat. Teresterial. Habitus. Perdu, tegak dengan tinggi 0,5-2 m. Akar. Tunggang. Batang. Berkayu, bulat, berbulu rapat atau bersisik, percabangan simpodial, berwarna coklat. Daun. Berbentuk bulat telur, ukuran 2-20 x 1-8 cm, berhadapan, ujung dan pangkal runcing, tepi rata, berbulu, pertulangan daun menjari, memiliki pertulangan daun sekunder (areolate). Perbungaan. Majemuk, kelopak berlekatan, berbulu, bagian ujung pendek dari pangkal, ujung meruncing, daun pelindung bersisik, ungu kemerahan, benang sari delapan sampai dua belas, panjang $\pm 3 \mathrm{~cm}$, merah muda, putik satu, kepala putik berbintik hijau, bakal buah beruang empat sampai enam, mahkota lima, bulat telur, ungu dan putih. Buah. Buni, bulat telur, ungu.

\section{Curculigo orchioides}

Habitat. Teresterial. Habitus. Herbaceus perennialberambut atau gundul, dengan rhizome tebal. Akar. Serabut pendek Batang. Herba, tegak. Daun. Daun tunggal biasanya 
bertangkai menggaris, termasuk herba berambut, panjang helaian daun mencapai $1.5 \mathrm{~m}$. Panjang tangkai daun dapat mencapai $1 \mathrm{~m}$; helaian daun berupa bangun jorong 30-100 cm x 5$10 \mathrm{~cm}$, agak gundul, ujung daun runcing, pangkal daun runcing, pertulangan daun sejajar. Bunga, tandan berwarna kuning, terendah dalam tandan 2 seksual, segmen perianth elips, lonjong, berbulu di bagian belakang. Buah,berupa kapsul, berasal dari rendah ovarium syncarpous tricarpellary.Biji, berwarna hitam dan lonjong.

\section{Coffea robusta}

Habitat. Teresterial. Habitus. Pohon berupa tanaman tahunan.Akar. Sistem akar tunggang, akar lembaga menjadi akar pokok yang akan bercabang menjadi akar yang kecil dengan mempunyai perakaran yang dangkal. Batang. Berkayukeras, tegak, putih ke abu-abuan. Daun.Daunnya bulat telur dengan ujungagak meruncing. daun tumbuh berhadapan pada batang, cabang, dan ranting-rantingnya. mengkilat, ujung runcing, tepi rata, pangkal tumpul, panjang 5-15 cm, lebar 4-6,5 cm, pertulangan menyirip, tangkai panjang 0,5-1 cm, warna daunhijau.

\section{Sauropus androgynus}

Habitat. Teresterial. Habitus. Terna. Akar. Tunggang. Batang. Berkayu, bulat, berwarna hijau kekuningan. Daun. Bentuk jorong, ujung runcing (acutus), pangkal runcing, pertulangan menyirip, tangkai daun $0,5 \mathrm{~cm}$, jarak antar nodus $4-6 \mathrm{~cm}$.
Bunga. Tunggal, aksilar, berwarna putih.

\section{Acalypha siamensis}

Habitat. Teresterial. Habitus. Terna. Akar. Tunggang. Batang. Berkayu, tegak. Daun. Bentuk jorong, ujung meruncing, tumpul, pangkal runcing, pertulangan menyirip, tepi bergerigi (serratus), berwarna hijau gelap, dalam satu nodus terdapat 2-3 helai daun, jarak nodus $2-3 \mathrm{~cm}$.

\section{Blamcanda chinensis}

Habitat. Teresterial. Habitus. Semak, tinggi 1-1,5 m.Akar.mempunyairimpang yang menjalar dan berwarna kuning dengan banyak akar serabut.Batang. Tegak, masif, pipih, berbuku-buku, halus, kuning kehijauan.Daun. Tunggal, menutupi batang, bangun daun lanset yang miring, tepi rata, ujung runcing, pangkal terbelah, pertulangan daun sejajar, panjang 50-60 cm, lebar 2-4 cm, warna daun hijau kebiruan,Daunnya tampak jelas 2 baris, berbentuk pelepah tinggi.

\section{Pellionia repens (Lour.) Merr}

Habitat. Teresterial. Habitus. terna, merambat. Akar. Serabut. Batang. Berkayu, Daun. Bentuk daun jorong (elliptic), ujung runcing (acutus), pangkal asimetri (inequlateral) hingga cordate, pertulangan menyirip, tepi berombak (sinuate),warna hijau pada bagian tepi dan krem pada bagian tengah. 


\section{Hydrocotyle spp}

Habitat. Teresterial. Habitus. Herba. Akar. Serabut. Batang. Herbaceus, ukuran 5-20 cm. Daun. Bentuk bangun ginjal,pangkal bertoreh (cordate), tepi creanate, pertulangan daun menjari, berwarna hijau terang, tangkai daun 10-20 cm. Perbungaan. Terminal, bentuk bongkol, berwarna putih, terdapat daun pembalut pada tiap bunga. Buah. Berbentuk bulat hingga bulat telur

\section{Pandanus spp}

Habitat.

Teresterial.

Habitus.Berupa perdu tahunan, tinggi 1-2 m.Batang. Bulat dengan bekas duduk daun, bercabang, menjalar, akar tunjang keluar di sekitar pangkal batang dan cabang. Daun. Tunggal, duduk, dengan pangkal memeluk batang, tersusun berbaris tiga dalam garis spiral. Helai daun berbentuk pita, tipis, licin, ujung runcing, tepi rata, bertulang sejajar, panjang $40-80 \mathrm{~cm}$, lebar $3-5 \mathrm{~cm}$, berduri tempel pada ibu tulang daun permukaan bawah bagian ujung-ujungnya, warna hijau.

\section{Musa acuminata}

Habitat. Teresterial. Habitus. Tumbuhan perrenial. Daun.Merupakan jenis daun tunggal dan termasuk daun sempurna karena bagian daunnya lengkap terdiri dari pelepah dauh, tangkai daun dan helaian daun. Daun pisang memiliki ujung daun meruncing, pangkal daun yang tidak seimbang antara kedua sisi disebut inequlateral, tepi daun rata, bangun daun jorong, daging daun seperti kertas, pertulangan daun (nervatio) yang menyirip, warna daun pada bagian atas berwarna hijau tua dan bagian bawahnya berwarna hijau muda yang mengkilat, serta bagian bawahnya berselaput lilin.

\section{Justicia gendarrusa}

Habitat. Teresterial. Habitus. Perdu, tegak, tinggi $\pm 1,8 \mathrm{~m}$. Tumbuh tegak, tinggi dapat mencapai $2 \mathrm{~m}$, percabangan banyak, dimulai dari dekat pangkal batang. Cabang-cabang yang masih muda berwarna ungu gelap, dan bila sudah tua warnanya menjadi coklat mengkilat.Batang. Berkayu, segiempat, bercabang, beruas, coklat. Daun.Daun letak berhadapan, berupa daun tunggal yang bentuknya lanset dengan panjang 5-20 cm, lebar $1-3,5 \mathrm{~cm}$, tepi rata, ujung daun meruncing, pangkal berbentuk biji bertangkai pendek antara 5 - 7,5 mm, warna daun hijau gelap.

\section{Strobilanthes spp}

Habitat.

Teresterial.

Habitus.Semak, tinggi 1-2 m. Akar. Tunggang dan berwarna coklat muda. Batang.Beruas, dengan diameter antara 0,12 - 0,7 cm,bentuk bulat,percabangan monopodial, warna batang hijau. Daun.Tunggal, bertangkai pendek, dengan duduk daun yang berhadapan. Helaian daunnya berbentuk bulat atau hampir lonjong, tepi daun berommbak dengan ujung dan pangkalnya yang meruncing, kedua permukaanya kasar. Pertulangan daunnya menyirip dan berwarna hijau. panjang helaian daun berkisar $\pm 5-8 \mathrm{~cm}$, lebar $\pm 2-5 \mathrm{~cm}$, warna permukaan daun bagian atas hijau tua sedangkan bagian bawah hijau muda. Perbungaan. Bunga majemuk, 
bentuk bulir, mahkota bunga bentuk corong, benang sari empat, dan warna bunga putih agak kekuningan. bijinya berbentuk bulat, dan ukurannya kecil. Sistem perakarannya tunggang, bentuk akar seperti tombak, dan berwarna putih.

\section{Costus speciosus}

Habitat. Teresterial, Habitus. Herba beraroma. Akar. Serabut, memiliki rhizome pada bagian bawahnya Batang. Herbaceous, lunak, berwarna hijau dan atau kemerahan, bisa mencapai tinggi sampai dengan 2 $m$ Daun. Berbentuk oblong atau oblanceolate, ujung runcing atau meruncing, kadang-kadang cuspidate, ukuran 15-30 cm, permukaan atas mengkilat, dan di permukaan bawah daun memiliki bulu halus yang lembut. Daun tersusun secara spiral pada batang Perbungaan. Berwarna putih, berada pada daun pembungkus yang tersusun spiral berwarna merah terang, berukuran 5-10 cm, kaliks dengan 3 lobe yang membulat, tabung corolla lebih pendek daripada kaliks dengan ukuran 2,5-4 cm

\section{Costus malortienus}

Habitat. Teresterial, Habitus. Semak dengan tinggi 0,6-1 m. Batang. Tegak, silindris, tidak bercabang, lunak, batang di dalam tanah mernbentuk rimpang. Daun. Tunggal, tata letak daun berseling, bangun daun bulat bulat hingga hampir lonjong, berpelepah, tepi rata, dengan ujung daun meruncing dan pangkal daun tumpul. panjang helaian daun $12-20 \mathrm{~cm}$ dengan lebar 8-14 cm, permukaan berbulu halus, pertulangan daun melengkung serta warna daun hijau mengkilat.

\section{Abrus spp}

Habitat. Teresterial. Habitus. berupa perdu merambat, membelit dengan panjang 6-9 m. Akar. berupa akar tunggang. Batang. Bulat, berkayu, percabangan simpodial, bila masih muda warnanya hijau dan setelah tua berwarna hijau kecoklatan. Daun. berupadaun majemuk, berselang-seling, menyirip ganjil, anak daun 8-18 pasang, bentuk daun bulat telur serta berukuran kecil-kecil. ujung meruncing dan pangkalnya bulat, tepi daun rata dengan panjang 6-25 $\mathrm{mm}$ dan lebar 3-8 $\mathrm{mm}$, berwarna hijau.

\section{Bauhinia spp}

Habitat. Teresterial, Habitus. Berupa tanaman perdu, tegak, dengan tinggi dapat mencapai hingga $3 \mathrm{~m}$. Akar. Akar tunggang. Akar lembaga menjadi akar pokok yang akan bercabang menjadi akar yang kecil. Batang. tegak dengan ranting muda berliku-liku dan berambut pendek. Batangnya berkayu dengan bentuk bulat dan tipe percabangannya simpodial. Daun.BangunDaun membulat telur sampai sedikit membulat, dengan ujung terbelah dua (retusus), Tepi daun rata (integer) karena tepi daun pada pangkal hingga ke ujung bertepi rata.Pangkal daun berlekuk dengan pertulangan menjari. Permukaan daun kasap (scaber).Daging daun seperti kertas dan tipis. Tangkai daun menebal pada ujung buku batang dan ujung pangkal daun 


\section{Davallia trichomonides}

Habitat. Teresterial, menempel pada batang kayu yang mati. Rhizome. Berambut halus, tersusun rapat dan panjang. merayap. Daun/Enthal. Daun runcing dan setiap batang memiliki daun yang sama sejajar tempatnya, menyirip ganda dua, tebal dan sedikit kaku, warna hijau tua; anak enthal berbagi. Sorus. Terdapat pada ujung anak enthal.

\section{Davallia spp}

Habitat. Teresterial. Batang. Berbentuk rimpang, berwarna coklat kehitaman teruntai halus dengan ukuran $\pm 0.2 \mathrm{~cm}$ dengan percabangan monopodial, Rimpangnya merayap Daun/Enthal. berbentuk segitiga, seperti kulit, ukuran sampai $1 \mathrm{~m}$, menyirip rangkap, anak daun bulat telur memanjang, beringgit, bergerigi dengan urat-urat yang bebas. Permukaan daunnya licin mengkilat, sehingga mudah sekali terlihat dengan jelas. Warna daun hijau sampai hijau tua, tangkai $15-60 \mathrm{~cm}$, tangkainya bewarna coklat gelap,mengkilat Sorus. sorus yang bulat, pada sisi bawah daun, diseluruh permukaan bawah daun, Indisium terdapat pada pangkal dan kanan kiri spesies ini. Dimana indusium berlekatan pada permukaan daun sehingga bentuknya kurang lebih seperti piala dan terbuka pada arah ketepi daun.

\section{Diplazium esculentum}

Habitat, Teresterial. Habitus. Berupa semak dengan tinggi 40-50 cm. Akar. Serabut, hitam. Rimpang. Pendek merayap 5 mm. Rhizoma. Merambat ke errect, bersisik: rimpang-sisik bergigi, malai berlekuk dengan lekukan khas dan membuk. Batang. Tegak nampak berdaging dengan ental banyak mencapai panjang $1,2 \mathrm{~m}$ lebih. Daun/Ental. Daun Majemuk, menyirip, lanset, tepi bergerigi, ujun runcing, pangkal tumpul, panjang 5-6 cm, lebar 1-2 cm, tangkai silindris, berambut, pertulangan menyirip, hijau. Enthal yang muda ditutupi oleh sisik berwarna coklat muda. Tersusun atas 15 pasang anak-anak daun panjangnya $40 \mathrm{~cm}$ dan lebarnya $8 \mathrm{~cm}$. Tekstur daun agak kaku dengan tepi bergigi berwarna hijau gelap. Sorus. Tumbuh di sepanjang urat anak daun pada ketiak anak daun tumbuh tunas untuk perbanyakan diri. Spora dihasilkan pada sporofil, terutama di permukaan bawah daun, berwarna coklat.

\section{Stenochlaena palustris}

Habitat. Teresterial.Habitus. Epifit dan bisa juga tumbuh di tanah, rimpang panjang-merayap, sering memanjat pohon tinggi. Daun/Enthal. Menyirip tunggal, dan tangkai daun berukuran 10-20 cm, yang cukup kuat. Daun mengkilat, gundul,, anak daunnya banyak, bertangkai pendek, berbentuk lanset, dengan lebar 1,5-4 cm, ujung daun meruncing. Tulang daun sejajar, bentuk daun jorong sempit, biasanya 15 $\times 3 \mathrm{~cm}$, meski selalu bervariasi ukurannya. Permukaan daun halus, mengkilap, warna hijau gelap, pucat di sisi bawah,tepinya bergerigi.

\section{Lygodium palmatum}

Habitat. Teresterial. Habitus. Herba. Akar. Rhizome merayap dengan 
pendek, tertutup rapat dengan rambutrambut kehitaman Batang. Membelit. Daun/Enthal. Susunan enthalnya menyirip, dengan bentuknya yang menjari 3, Tepi ental rata dan berwarna pucat. Pada ental yang subur, sporangianya terletak di tepi ujungujung gerigi ental, enthal seperti kertas yang halus, gundul kecuali jarang rambutnya pada lapisan yang utama; daun yang fertile sama dalam sistem percabangan sampai daun yang steril, lebih sempit, lebarnya kurang dari 1 $\mathrm{cm}$. Sorus.sporangia mengandung cuping yang menonjol, banyak pada bagian tepi dari daun tersier dengan panjang 2-5 mm dan lebar sekitar 1.2 $\mathrm{mm}$ dan indusium gundul.

\section{Lygodium circinatum}

Habitat. Teresterial. Habitus. Herba. Akar. Rhizome merayap dengan pendek, tertutup rapat dengan rambutrambut kehitaman Batang. Membelit. Daun/Enthal. Susunan enthalnya menyirip, dengan bentuknya yang menjari antara 2-5. Kadang-kadang paku ini bercabang dua dan setiap percabangan bercabang dua lagi, Tepi ental bergerigi dan berwarna pucat. Pada ental yang subur, sporangianya terletak di tepi ujung-ujung gerigi ental, Daun steril dengan 2-7 cuping plamate terbagi dengan dasar cuneate, cuping secara bertahap menyempit terhadap ujung yang tajam, menyeluruh pada bagaian tepi,mencapai panjang $20 \mathrm{~cm}$ dan lebar lebih dari $2 \mathrm{~cm}$, kadangkadang daun fertile pada bagian yang lebih tinggi; enthal seperti kertas yang halus, gundul kecuali jarang rambutnya pada lapisan yang utama; daun yang fertile sama dalam sistem percabangan sampai daun yang steril, lebih sempit, lebarnya kurang dari $1 \mathrm{~cm}$. Sorus.sporangia mengandung cuping yang menonjol, banyak pada bagian tepi dari daun tersier dengan panjang 2-5 $\mathrm{mm}$ dan lebar sekitar $1.2 \mathrm{~mm}$ dan indusium gundul.

\section{Angiopteris evecta}

Habitat. Teresterial. Batang. Tegak, berbulu halus, merupakan tumbuhan paku yang besar. Daun/Enthal. berukuran daunnya 2-5 meter, menyirip ganda 2-4 anak daun menyerupai daun kedondong. Sorus. Memanjang, sporangium di dalamnya bebas.

\section{Phymatosorus scolopendria (Burm. f) Pic. Serm.}

Habitat. Teresterial. Habitus. terna berkayu. Akar. Memiliki rhizome, merambat, berwarna coklat gelap. Batang. Tegak berkayu. Daun/Enthal. Bentuk deltate-ovate, coriaceous, glabrous, berukuran $60 \times 30 \mathrm{~cm}$, terbagi menjadi 4-8 pasangan, dan satu helai pada bagian atas, ujung runcing, tepi rata. Sorus.berukuran diameter 2-3 $\mathrm{mm}$, tersusun pada bagian bawah, di sepanjang pertulangan daun.

\section{Adiantum latifolium}

Habitat. Teresterial. Batang. Rimpang panjang-merayap, 2-3 mm dan ditutupi dengan sisik coklat pucat, Stipe berwarna coklat sampai hitam dan panjang 25-50 cm. Daun/enthal. Berukuran 20-40 x 18-30cm, bipinnate di dasar, menyirip sederhana di puncak, pinnules yang membagi dua, lonjong ke 
segitiga, kadang-kadang sedikit berbentuk sabit, lebih atau kurang sessile dan 1,5-6 x 0,5-1,6 cm, margin dari pinnules steril bergerigi.

\section{Pteris spp}

Habitat. Teresterial. Habitus. Tumbuhan herba atau agak berkayu. Akar. Serabut yang tidak bercabang atau monopodial. Terletak pada seluruh permukaan rimpang, bentuk akar tipis dan kasar berwarna coklat. Batang. berbatang pendek, yang tumbuh tegak. Bentuk batangnya bulat simetridorsiventral dan tumbuh tegak memanjang. Tangkai entalnya licin ada yang berwarna ungu gelap kehitaman, mengkilap, memanjang, menyamping keseluruhan. Permukaan batang terdapat ramenta yaitu bentukan seperti rambut atau sisik yang halus ada yang berwarna hitam, coklat kehitaman, merah kecoklatan, kuning kecoklatan, kuning dan kadang-kadang putih (tergantung jenisnya) yang terdapat pada rimpang atau sering pula pada tangkai daun, tulang dan urat daun. Daun/Enthal. Membujur panjang yang berbentuk pisau pembedah, berjumlah 1 - 4 menyirip, merupakan rumput-rumputan kasar, abxial dan adaxial glabrous atau kadang-kadang bersisik, adaxial tumpul, tulang punggung lurus. Segmen-segmen terakhir dari helaian tangkai sessile pendek, linear membujur-berbentuk pisau pembedah, lebar 1,5-8 $\mathrm{mm}$, bagian dasar menyempit atau yang membatasi dengan tangkai.

\section{Dryopteris spp1}

Habitat. Teresterial. Habitus. Herba agak berkayu. Akar. Serabut bercabang-cabang secara dikotom, dan berwarna coklat.Batang. Berupa rimpang yakni tegak, panjang dan ramping, dimana permukaannya halus serta berwarna coklat. Batang tidak bercabang, dan berbulu halus. Daun/Enthal. Bentuk delta dengan tepi bersirip-sirip (pinna), daunnya sporofil yakni terdapat spora di bagian ventral. Ujungnya meruncing, tepi bercangap, ukuran daun terdiri dari 2 ukuran yaitu satu lebih besar dan yang satu lebih kecil (anisofil). Warna daun Hijau kecoklatan, tekstur daun berbentuk helaian, permukaan ventral daun ditutupi spora, bagian dorsalnya halus. Termasuk daun majemuk menyirip, daun dimorfisme yakni dalam 1 tangkai ada daun tropofil dan sporofil, di bagian ventral sporofil dan dorsal tropofil. Sorus. (sori) berkelompok. Sporangium berbentuk ginjal, bertangkai dengan anulus vertikal, tidak sempurna.

\section{Dryopteris spp2}

Habitat. Teresterial. Habitus.

Terna. Akar. Berbentuk serabut bercabang - cabang dikotom berwarna coklat. Batang. Berupa rimpang yang tegak panjang dan ramping, permukaannya halus dan berwarna coklat, batangnya tidak bercabang. Daun/Enthal. Termasuk daun majemuk menyirip, bangun daun bentuk delta dengan tepi daun bergigi, daunnya sporofil yakni terdapat spora di bagian ventral. ujungnya meruncing, Warna daun Hijau muda mengkilat, tekstur daun berbentuk helaian, 
permukaan ventral daun ditutupi spora, bagian dorsalnya halus.

\section{Dryopteris spp3}

Habitat. Teresterial. Habitus. Herba agak berkayu, Akar. Berbentuk serabut bercabang-cabang dikotom berwarna coklat. Batang. Berupa rimpang yang tegak panjang dan ramping, permukaannya halus dan berwarna coklat, batangnya tidak bercabang. Daun/Enthal. Termasuk daun majemuk menyirip ganda sampai beberapa kali dengan urat - urat daun bebas. Bentuk/bangun daun lanset tepi bergerigi halus, ujungnya meruncing, Warna daun Hijau kecoklatan, tekstur daun berbentuk helaian, permukaan ventral daun ditutupi spora. Panjang daun 15-20 cm dengan lebar kira-kira 1 $\mathrm{cm}$. Sorus. Bulat atau lonjong, kebanyakan terletak pada \pm di tengah tengah urat bagian bawah daun.

\section{Gleichenia linearis}

Habitat. Teresterial. Habitus. Semak atau perdu. Akar. Berupa akar rimpang yang tumbuh di dekat permukaan tanah dan keluar batang keras yang tumbuh keatas. Batang, tumbuh melilit dan bercabang seperti garpu. Batang. Merayap, sering membentuk jalinan 'sheet' yang rapat, tidak begitu kelihatan. Karena tumbuhnya menyerupai akar, maka batangnya sering disebut rhizoma. Daun/Enthal. Peletakan daunnya menyirip berjajar dua dan tangkainya bercabang mendua (dikotom). Daun panjang dengan bagian-bagian yang menyirip. Ujungnya sering sampai lama dalam kedaan kuncup.Daun berjauhan satu dengan yang lain, tidak beruas, bercabang menggarpu dua kali sampai banyak kali. Pada tiap cabang kecuali yang teratas, terdapat dua segment daun yang melintang dan membengkok, panjangnya $5-25 \mathrm{~cm}$. Dekat langsung di bawah garpu yang termuda terdapat tangkai yang tidak berdaun, juga semua tangkai yang lebih bawah tidak berdaun. Tajuk daun berbentuk pita memanjang, panjangnya $18-75 \mathrm{~mm}$, licin, tepinya rata, ujungnya tumpul dan sedikit menggulung, pada tiap taju daun umumnya terdapat sori lebih dari satu. Sorus. Terdapat pada setiap anak daun dan penyebarannya terbatas di sepanjang tulang daunnya. Masing masing sorus terdiri atas kira-kira 1015 sporangia.

\section{Gleichenia truncata}

Habitat. Teresterial. Habitus. Semak atau perdu. Akar. Akar merupakan rimpang yang disebut dengan nama rhizoma. Tunas tumbuh dari akar rimpang ini berwarna hijau pucat yang ditutup oleh bulu-bulu berwarna hitam Batang.Merayap, Ranting pada batang memiliki banyak cabang, semua ranting kecuali segmen basal atau dasar, Daun/Enthal. Daun panjang dengan bagian-bagian yang menyirip. Daun berjauhan satu dengan yang lain, tidak beruas, bercabang menggarpu dua kali sampai banyak kali. Semua daun, masing-masing ranting panjangnya $7.5-12 \mathrm{~cm}$, lobusnya tetap, daun bagian bawah kasar, biasanya mempunyai panjang yang tidak teratur pada setiap ranting. Kira-kira panjangnya adalah $3.5 \mathrm{~cm}$, lebarnya adalah $2.5 \mathrm{~mm}$. permukaan daun licin 
berwarna hijau muda, tepinya rata, ujungnya tumpul dan sedikit menggulung, pada tiap taju daun umumnya terdapat sori lebih dari satu. Sorus. Terdapat pada setiap anak daun dan penyebarannya terbatas di sepanjang tulang daunnya.

\section{Nephrolepis biserrata}

Habitat. Teresterial. Akar. Serabut, berwarna hitam. Batang, bulat ramping dan memanjang berwarna hijau. Daun/Enthal. Tangkai daunnya bersisik lembut, sisik-sisik tersebut berwarna coklat. Bentuk daun subur lebih besar dari daun mandul, pada daun subur bentunya lancip dengan dasar yang berkuping. Sorus, Sporanya dipinggir daun.

\section{Selaginella willdenowii}

Habitat. Teresterial. Habitus. Herba agak berkayu. Batang. Merayap (prostrate) dan menjalar yang bercabang-cabang pada jarak pendek. Batangnya tegak dan bersisik halus. Kadang-kadang mempunyai percabangan yang menyirip. Percabangannnya monopodial walaupun dekat titik tumbuh itu tampaknya dikotomi. Batang memiliki banyak daun kecil-kecil yang dipisahkan oleh ruas yang jelas pada bagian yang lebih tua. Daun/Enthal. Berwarna hijau Entalnya berbentuk bulat lonjong, kecil dan kaku, menggerombol di ujung batang sehingga tampak menutupi batangnya. Daun kecil , tunggal , pada cabang saping tersusun dalam 4 baris, yaitu 2 baris samping terdiri dari daun besar yang kerapkali mudah rontok , 2 baris terdepan berdaun kecil yang duduknya menempel (Pada bagian batang yang lebih rendah kedua macam daun ini hampr atau sama sekali serupa satu sana lain.Pada bagian bawah sisi atas daun terdapat suatu sisik yang dinamakan lidah-lidah (ligula) yang merupakan alat penghisap air).

\section{Asplenium nidus}

Habitat. Teresterial. Habitus. Tumbuhan epifit, tumbuh epifit di batang pohon yang telah ditebang sampai di ranting pohon besar. Akar. Rimpang kokoh, tegak, bagian ujung mendukung daun-daun yang tersusun roset, di bagian bawahnya terdapat kumpulan akar yang besar dan rambut berwarna coklat, bagian ujung ditutupi sisik-sisik sepanjang sampai $2 \mathrm{~cm}$, berwarna coklat hitam. Batang.Dapat berupa batang dalam (rizom) atau batang di atas permukaan tanahyang pendek ditutupi oleh sisik yang halus dan lebat, sisik berwarna coklat. Daun/Enthal. Daun berupa daun tunggal lanset (lanceolatus) dapat mencapai panjang $150 \mathrm{~cm}$ dan lebar $20 \mathrm{~cm}$, menyerupai daun pisang, ujung daun meruncing atau membulat, tepi rata dengan permukaan yang berombak dan mengkilat. Warna daun bagian bawah lebih pucat dengan garis-garis coklat sepanjang anak tulang daunnya. Tulang daun menonjol dipermukaan atas dan rata dipermukaan bawah.Peruratan daun menyirip tunggal. Warna helai daun hijau cerah, dan menguning bila terkena cahaya matahari langsung.Ental-ental yang mengering akan membentuk semacam "sarang" yang menumpang pada 
cabang-cabang pohon. Ujung daun meruncing (acuminatus) dan tepi daun berombak (repandus).Sorus.Terdapat di bawah daun berbentuk garis-garis berwarna coklat kehitaman yang terdapat di sepanjang anak tulang daun.Spora terletak di sisi bawah helai, pada urat-urat daun, dengan sori tertutup semacam kantung memanjang.

\section{SIMPULAN}

Dari hasil yang telah diperoleh, maka dapat disimpulkan bahwa terdapat 48 jenis tumbuhan bawah yang terdiri dari 31 famili. Dari 48 jenis yang ditemukan, 30 diantaranya termasuk ke dalam divisi Spermatophyta, sedangkan 18 lain sisanya adalah termasuk ke dalam divisi Pterydophyta. Famili dari divisi Spermatophyta yang paling banyak ditemukan jenisnya adalah famili Araceae sebanyak 6 jenis, Famili dari divisi Pterydophyta yang paling banyak ditemukan jenisnya adalah famili Dryopteriaceae sebanyak 3 jenis.

\section{DAFTAR PUSTAKA}

.2009. Komposisi Spesies dan Pola Penyebaran Tumbuhan Bawah Pada Komunitas Hutan Yang Dikelola Petani Register 19 Propinsi Lampung.. Lampung: UNILA

Baker, F. S., T. W. Daniel, J. A. Helms. 1979. Principles of Silviculture. New York: McGraw-Hill Inc. Book Co.

Indriyanto. 2006. Ekologi Hutan. Jakarta: Penerbit PT Bumi Aksara.

Polunin, N. 1997. Pengantar Geografi Tumbuhan dan Beberapa Ilmu Serumpun. Yogyakarta: Gadjah Mada University Press.

Rugayah, Retnowati A, Windadri FI, Hidayat A. 2004. Pengumpulan Data Taksonomi. Di dalam: Rugayah, Widjaja EA, Praptiwi, editor. Pedoman Pengumpulan Data
Keanekaragaman Flora. Bogor: Puslit Biologi LIPI. 